\title{
Deconstructing Attitudes towards Plagiarism of Japanese Undergraduates in EFL Academic Writing Classes
}

\author{
Jennifer Teeter ${ }^{1}$ \\ ${ }^{1}$ Kyoto University, Japan \\ Correspondence: Jennifer Teeter, Kyoto University, Japan. E-mail: teeter42@gmail.com
}

Received: September 22, 2014 Accepted: October 23, 2014 Online Published: December 17, 2014

doi:10.5539/elt.v8n1p95 URL: http://dx.doi.org/10.5539/elt.v8n1p95

\begin{abstract}
In this study, a qualitative analysis of 276 first-year Japanese university science major responses to plagiarism to deconstruct prevailing generalizations regarding the incidence of plagiarism by Japanese university students. These students were enrolled in a compulsory yearlong English academic writing course. While utilizing a contextualized incident, rather than generalized statements, to gain a more thorough understanding of students' perceptions of plagiarism, this study also seeks to address the current imbalances in English-language analyses on plagiarism in Japan which fail to incorporate Japanese-language sources and studies. In contrast to previous research based on hypotheses of cultural conditioning which assume students are ambivalent towards plagiarism, the students surveyed displayed a complex awareness of the educational and societal issues that frame occurrences of plagiarism and a desire to receive effective training in academic writing techniques, similar to their native English-speaking counterparts. Finally, the paper makes suggestions for pedagogy that empowers students with tools to critically navigate the dominant academic world.
\end{abstract}

Keywords: academic writing, ESL, EFL, culture, Japan, plagiarism, science majors, university

\section{Introduction}

In recent years, how to handle plagiarism is a growing concern throughout the world (Bretag et al., 2013), especially in English as a Foreign Language classes (Day, 2009; Pennycook, 1996; Wheeler, 2009). In Japan particularly, the recent controversy regarding the potentially fabricated and plagiarized work of a Japanese stem-cell biologist Dr. Haruko Obokata, who reported the discovery of a new type of pluri-potent stem cell that can repair human tissue, has flooded the airwaves while shaking scientific communities world-wide. The implications of this incident are a cause for concern, as previous and often cited examination of attitudes towards plagiarism by Rinnert and Kobayashi (2005) indicate that students in Japan do not take plagiarism seriously. Furthermore, other scholars have made sweeping generalizations to the effect that plagiarism is accepted in Asian cultures (Dryden, 1999; Connolly, 2009, Sowden, 2005). The moral standing of Dr. Obokata put aside, given the stricter regulations being enacted in regards to academic honesty in universities and research institutes nationwide since the incident, from first-year to doctoral level, scholars are now provided an opportunity re-examine student attitudes towards plagiarism and develop effective academic writing teaching devices to ensure future scholars know how to avoid plagiarism.

Therefore, using the Obokata incident as a prompt for exploration, this paper will examine the attitudes towards plagiarism of first-year science majors enrolled at a leading national university in Japan. Based on 2012 data, since $85-95 \%$ of these students matriculate onto graduate school and of these students over $50 \%$ carry on to doctoral studies tutelage on ethics in academic paper writing and publishing is necessary. First, it will examine existing literature on plagiarism education in the Japanese context and analyze previous studies conducted on attitudes towards plagiarism. Next, it will detail and analyze the results of a qualitative study on students' attitudes regarding plagiarism derived from short essays responses on student attitudes towards plagiarism. A thematic narrative analysis (see Boyatzis, 1998; Riessman, 2005, 2008) will be conducted on the student accounts.

Furthermore, throughout the paper, the author will attempt to address the lack of incorporation of Japanese language sources in the study of plagiarism in Japan. While highlighting the rich and multi-layered interactions that university students maintain with the concept of plagiarism, it will present further evidence to challenge common discourse that asserts that Japanese students are ambivalent towards copying and plagiarism due to their 
improperly and stereotypically termed "culture of memorization." Similar to Liu (2005), it acknowledges that there are occasions where memorization is a useful technique for study, and where utilizing the work of previous authors without referencing may be acceptable. Regardless, it is written with the assumption that a perceived correlation between any culture that values memorization as a method of study, and plagiarism is largely misguided.

\section{Literature Review}

\subsection{Definitions of Plagiarism}

In its definitions of academic dishonesty, the Kagakugijutsu Gakujitsu Shingikai Kenkyū Katsudō no Fusei Kōi ni Kansuru Tokubetsuīnkai (Special Committee on Academic Dishonesty in Research of the Commission of Inquiry on Science and Technology (2006, p. 12) of the Japanese Ministry of Education, Culture, Sports, Science and Technology (MEXT) describes plagiarism as "the appropriation of another researcher's ideas, analysis, analytical process, data research, results, articles/terminology without the researcher's prior consent and/or proper acknowledgment." Similarly, the U.S. Office of Research Integrity which examines cases of scholarly misconduct utilizes the definition provided by the U.S. Department of Health and Public Services (2005) maintaining "plagiarism is the appropriation of another person's ideas, processes, results, or words without giving appropriate credit...the misconduct be committed intentionally, knowingly, or recklessly" (p. 28386). Both of these Japanese and U.S. definitions leave no leeway for unintentional, or inadvertent plagiarism. However, further research needs to be conducted on whether these institutional definitions actually reach students, and if they do, which students they are reaching.

Despite the possibility of students/academics unintentionally plagiarizing either due to uncertainty regarding when to cite source material or inadequate training in proper paraphrasing techniques (Newton, Wright, \& Newton, 2014), plagiarism is often framed by academia as an inexcusable offense. Yet ironically as reported in the same academic journal in which Obokata was accused of plagiarism, this "immoral" act persists as the "most common of accusations of misconduct against academics" (Maddox, 1995, p. 721). This high frequency raises questions regarding the instruction received by academic scholars in research techniques in general, which will be covered in the next section.

\subsection{Plagiarism in Native-English Speaking and ESL/EFL Contexts}

Discussion about plagiarism takes on a different tone depending on the language context. Previous discussions on plagiarism in so-called Western contexts have been shaped by repugnance towards the moral offense- it is a crime "worse than theft" (Maddox, 1995). In ESL/EFL contexts, debate revolves around whether or not educators should increase their tolerance and understanding of the impacts of cultural difference on writing practices, including plagiarism (Day, 2009; Pennycook, 1996; Wheeler, 2009).

Post-modern thought on student copying in a second language, especially English, supports the view that remnants of colonial rhetoric can shape the handling of the situation. As elaborated by Pennycook (1996), teachers can become caught in a dialectic of searching for mistakes and inadequacies in writing based on preconceived notions of fluency in determining whether a piece has been written in the student's own words. In order to overcome what Hutton (1990 in Pennycook, 1996, p. 203) refers to as a "paradoxical state," Pennycook (1996) argues teachers must recognize the complex and nuanced natures of conceptions of plagiarism. Even in Western thought, the concept of ownership of ideas is a relatively new one framed by an ebb and flow between creativity being defined by production and reproduction.

Pennycook's treatise on plagiarism, however, is often misconstrued by researchers. Although Pennycook succinctly indicates that he "want[s] to avoid simplistic arguments such as 'it's OK to plagiarise in Chinese" (Pennycook, 1996, p. 218), researchers fail to realize that his arguments are intended to emphasize differing relationships with texts, not cultural permissibility of copying other people's work. His suggestion to educators is to acknowledge that "language learning is to some extent a process of borrowing others' words and we need to be flexible, not dogmatic, about where we draw boundaries between acceptable or unacceptable textual borrowings" (Pennycook, 1996, p. 227).

While cultural tolerance is a virtue in any classroom, arguments that assert that plagiarism is accepted by Asian societies, are based on cultural stereotype and illogical jumps in reasoning. For instance, in one discussion of the impact on Japanese culture on Japanese students' usage of text, the author asserts that "the tendency to copy freely from published sources seems only natural" (Dryden, 1999, p. 83). Another discussion on the essay writing practices of "Asian" students in general, alleges:

Asian students typically have been schooled to memorize and reiterate verbatim large amounts of material, both 
from written sources and from professors' lectures...this tradition explains why Asian students often meticulously and exactly reproduce material from sources provided (Connolly, 2009).

Drawing on anecdotal conversations with students for the basis of his arguments, Sowden (2005, p. 227) contends that it can be inappropriate to expect students to write in their words because the low tolerance for ambiguity and emphasis on master-apprentice style education of some cultures creates a situation where "plagiarism can be seen as a virtue: producing what you know to be correct." In the Japanese context, the author's informal interviews with "native" English speaker educators in Japan have shed light on a pervasive and culturally imperialistic discourse, which frames Japanese students as unable to do more than copy other people's work.

Furthermore, an unsubstantiated belief that native English writers plagiarize less than their non-native English counterparts forms a faulty foundation of this discourse. While taking into account that methodology plays a significant role in determining rates of student plagiarism, findings suggest that rates of plagiarism by native English speakers are also of significant concern. The results of several studies in the UK on student beliefs regarding plagiarism indicate that university students believe that plagiarism and academic dishonesty occurs at high rates. One study found that students believed that the frequency of copying without references and paraphrasing without references was 54\% and 60\% respectively (Franklyn-Stokes \& Newstead, 1995, p. 164). Results of another questionnaire conducted in the UK found that students presume that the copying of segments from a source without references occurs at a frequency of $74 \%$ (Dordoy, 2002, p. 2). In Australia, $81 \%$ of 954 undergraduate students from four Australian universities surveyed self-reported plagiarizing (Marsden, Carroll, $\&$ Neill, 2005, pp. 4, 8). The results of a recent Australian survey of over 15,000 undergraduates led the researchers to conclude that although students exhibited high levels of awareness regarding the importance of maintaining academic integrity, more emphasis providing thorough training on how to ensure academic integrity is paramount (Bretag et al., 2013).

Therefore, the type of essentialist rhetoric regarding non-native learners of English, and of Asian students in general, underestimates the talent of students by making exceptions based on false cultural assumptions. Liu (2004) argues that much of the discourse on "Asian students" is historically inaccurate and condescending, elaborating on the extent to which plagiarism is frowned upon in China. He points to practices stemming back to ancient China, the emphasis on not copying other people's work by teachers in L1 composition writing classes and textbooks, and recent governmental initiatives to decrease the incidences of plagiarism. Assuming that just because plagiarism occurs in China, it is accepted by Chinese, or it is the main reason students plagiarize, especially in their second language, is a logical fallacy. Likewise, Le Ha (2006) debunks these stereotypes of Asians, showing that although culturally specific characteristics can be found in Vietnamese academic writing, plagiarism is inherently not allowed.

In a similar light, these essentialist arguments about Japan are verging on nihonjinron discourse (Bailey, 2002; Wheeler, 2009) a type of discourse utilized in struggles for power by Japanese leaders, which frame Japan as a unique, group-oriented, homogenous society. As Kubota (1999) explains, nihonjinron rhetoric in the ESL/EFL context informs educators to disregard the subjective voices of students, and encourages a vicious circle of Other-ing, which in turn allows for the continued appropriation of this "unique" Japanese culture for political purposes. She emphasizes the importance of deconstructing nihonjinron-like discussion through a "critical multiculturalism" that positions discourse in social, economic, and historical perspectives allowing for critical analysis of social and economic power relations and the production of difference/Otherness (p. 27). Acknowledging cultural difference is not enough - through understanding how difference is produced via social and economic institution is paramount. In order to understand how this difference is produced through discourse, practitioners must go beyond simply affirming and respecting the culture of the perceived Other. This only serves to romanticize its authentic voices- practitioners need to critically explore how cultural differences as a form of knowledge are produced and perpetuated. This leads to student empowerment as the subjective voice is seen as a site of struggle in the examinations of the social and historical contexts that lead to discrepancies in the way plagiarism, and writing in second languages, is conceived.

In their studies on L2 writing, Pecorari (2003) and Wheeler (2009) note that rather than culture norms dictating students' inability to write with proper citations and paraphrases, the likelihood that plagiarism occurs because students have still not developed their full writing capabilities is higher. This holds true for native and non-native speakers entering university (Macbeth, 2006). Along the same line of reasoning, ample evidence supports the notion that thorough training in academic writing at the university level in Japan effectively contributes to a decrease in the incidence of plagiarism in both Japanese (Kobayashi, 2010; Nishigaki, 2012) and EFL academic writing (Shibata, 2011). 


\subsection{Japanese Elementary School through University Academic Writing Tutelage}

As noted previously, valuable contextual information is lost when Japanese-language sources are left out of discussions of plagiarism in Japan. The majority of English-language research on plagiarism in Japan tends to neglect research and studies conducted by scholars in the Japanese language regarding techniques for teaching students to write in their own words, proper citation techniques, and plagiarism in general (Hoshino, 2008; Kobayashi, 2010; Nishigaki, 2012; Oshima, 2010; Sadoshima, 2008, 2014; Yamamoto, 2001). Much of this research focuses on academic writing in the L1, though research in Japanese on L2 academic writing also exists (Shibata, 2011). While taking into consideration the arguments of Liu $(2005$, p. 239) that plagiarism in the L2 is often times language-specific, frequently stemming from "a lack of adequate language proficiency, lack of task-specific writing skills, and, of course, the urge to cheat," this paper argues that students, due to their pre-university level training, are aware to some extent that referencing of sources is an important part of academic writing in any language and that copying other people's work is not acceptable. This is reinforced by how some degree of skill transfer occurs between subjects, and also between study in the L1 and L2 (Klein, 1990). Not acknowledging the work of Japanese scholars does the injustice of painting an incomplete picture of the work, thinking and expertise of scholars and educators writing in the Japanese language.

Sadoshima (2008) notes that in elementary and junior high schools, textbooks provide explicit instruction to students on how to references sources of their writing. The most widely used textbook on writing in Japanese elementary schools, Mitsumura Tosho's Kokugo sanshita: Aozora (Blue sky: Japanese 3rd year second semester) (2012, p. 144) spe specifically instructs students to write, "I found this out after reading X book" in the textbook used by $3^{\text {rd }}$ year, second semester students when they write a summary. Nonetheless, Sadoshima (2008) argues that junior high school textbooks lack the scaffolding that allows students to become accustomed to cite sources of information. Kokugo (2013) for years 1, 2, 3, unfortunately, only provide instructions to use citations, neglecting to explain the process and why proper citation is important.

If this is the only instruction received, students face the risk of matriculating onto high school with no practical knowledge on citation and referencing. Furthermore, since students are not required to write references in their essays for entrance into universities, education on citing sources tends to be skipped over (Sadoshima, 2014). Despite this, Sadoshima's (2014) survey research conducted at the university level demonstrates that students are overwhelmingly aware that paraphrasing and proper referencing is necessary. Furthermore, research conducted in English academic writing classes at the University of Tokyo concluded that students found writing references to be moderately difficult, however less difficult than other tasks required in academic English writing (Lee \& Tajino, 2008).

Attitudes towards plagiarism are also considered to influence a student's choice to plagiarize. Rinnert and Kobayashi's (2005) study is frequently cited in analysis of Japanese student attitudes towards plagiarism. They conclude in their analysis of difference in perceptions towards plagiarism in the U.S. and Japan that Japanese students feel more tolerant of plagiarism. In spite of this, the issue is not whether or not Japanese students have a higher generosity towards plagiarism or not, but more related to pedagogy concerns. If we examine the results of their survey of 605 Japanese students, the majority of students reported they received only a "fair amount" of instruction on referencing, a semi-fair amount of training on summarizing and quoting correctly, and not a sufficient amount of training on paraphrasing (Rinnert \& Kobayashi, 2005, p. 38).

While the results of this survey also found that the majority of students either felt that avoiding plagiarism was "not very important" or "somewhat important" (Rinnert \& Kobayashi, 2005, p. 39), cultural interpretations of terminology and cultural context may have played a role in the results. The authors noted that the prevalence of this response could be accredited to the translation of the term "plagiarism" in the questionnaire. Throughout the questionnaire in Japanese, instead of using the term for plagiarism that is more technical and has a negative connotation, tōsaku, the word ukeuri which has less negative connotation (although tōsaku was often used in several questions). Rinnert and Kobayashi argued that ukeuri would be closer in meaning to plagiarism because tōsaku the former term is "generally not used or understood by our students" (Rinnert \& Kobayashi, 2005, p. 36).

To confirm this understanding of students' knowledge of these terms, the author informally interviewed students in English to determine which word they would use, asking students "which word would you use for copying and pasting information from one paper into another, or using the ideas of someone else's paper in their own without saying the original author." All of the university students reported that they use word tōsaku. When I asked them if they would use the word ukeuri, they expressed that they would not. One student elaborated,

Mukashi tsukatte ita kamo shirenai kedo, ima wa tōsaku. Ukeuri wa dōyuu imi de tsukatte iru no ka yoku 
wakarahen (People probably used it a long time ago, but now the word tōsaku is used. If someone were to use the word ukeuri now, I wouldn't really know what they mean by it) (translation by author).

In order to further confirm which term is commonly used, I also informally interviewed Japanese teachers of writing in both the Japanese and English languages and they also stated that they use the word tosaku and that "it would not make sense" to use ukeuri.

While it is impossible at this point to determine whether the use of tōsaku in the Rinnert and Kobayashi (2005) questionnaire made a difference, there are several implications. Using tōsaku could have resulted in more unfavorable response towards plagiarism. It might have been the terminology used ten years ago, but it is likely that it would have made a difference because ukeuri does not have a strong negative connotation, while tōsaku implies it is a morally/ethically wrong deed that warrants punishment. Another possibility for consideration is that discussion of plagiarism has gained traction over the past 10 years in Japanese educational institutions, causing students to be more familiar with more technical terms for plagiarism.

Another reason for these results might be due to different interpretations of the word "report" in English and Japanese. In Japan, "reports" may not be given as much weight as in the United States. United States. Furthermore, in a large proportion of cases, teachers do not always give feedback to students on reports in Japan. A research paper or a thesis would be considered more important to students in Japan. This term "report" must also be taken into consideration given the context of universities in Japan, where students could be enrolled in as many as 25 different classes a semester. Finally, students could also have been answering the question about plagiarism relative to other answers, which is a common behavioral pattern of respondents when answering questions on Likert scales.

Being aware of cultural arguments is important for educators, but what is more important is to prepare students to be aware of the expectations in different academic contexts while acknowledging difference. This type of compromise not only respects students' abilities, but also acknowledges potential cultural differences.

Given the tenuous nature of the studies and theories that contend that Asian and Japanese students are more culturally inclined to plagiarize, coupled with efforts of Japanese educators to teach students how to avoid plagiarism and coinciding international and Japanese conceptions of plagiarism on the institutional level, it is necessary to find new ways of coming to grasps with perceptions of students towards plagiarism. The next section will describe a thematic narrative study which attempts to address this problem with conclusions of much of the current literature.

\section{Research Methods}

\subsection{Participants and Pedagogic Space}

In total, there were 338 (64 women, 274 men) first year students (ages 18-20) in 10 different classes at a Kyoto University in Japan enrolled in the author's compulsory introductory courses on English academic writing over one semester from April to July 2014. The majority of the students' majors were related to science (agriculture and engineering), though there were three classes in the liberal arts (economics, education, and integrated human studies). The majority of students spoke Japanese as a native language, or at a level of proficiency to be able to enroll in the university. The countries of origin of exchange students included Bulgaria (1 student), China (5 students), and Korea (3 students). Although there are no official records of students' proficiency levels in English, independent studies of students enrolled in the school have found that students' average TOEFL score is around 78 compared to the average of 65 for all Japanese people (Aotani, 2013).

The functional design of an educational space intertwines with symbolic elements in ways that can bring together or separate people (Apple, 1993). The pedagogical space of this study featured classrooms where each student had access to a computer which was, in theory, connected my computer through a system called CaLabo. The computers were arranged in rows, facing the front of the classroom with the teacher's desk at the right side of the front of the room. Wheels on the students' seats allowed them to be semi-mobile. The design of the classroom while uniting students in some manners, also provided some barriers as well.

The students could communicate with the author/teacher and each other through the CaLabo system through chat messages or headsets. Depending on the class day and time, there were 30-40 students in each class. The author could view the screens of the students from her computer, showcase student work on their computers to the entire class, and assist students having difficulties. However, normally, the author utilized person-to-person approaches to interact with the students, due to the unnecessary distance between teacher and student that results from overreliance on this technology. Students displayed a tendency to prefer speaking face-to-face. Furthermore, technical errors with the computers were abundant, but did not present a large burden to conducting the class, but 
rather, an opportunity.

Students' prior experience with computers also varied, but as the semester progressed students assisted each other more actively in using the computers. While this is beyond the scope of the paper, it is important to note that the author sensed a degree of embarrassment by students for not being able to use the computers as they desired and a hesitance to ask for help in some circumstances. Nonetheless, a lack of knowledge of the computers transformed from a self-perceived disability, to a way to start conversation amongst students and teacher. At the beginning of the semester, students did not move from their desks and had a tendency to look at their computer screens, but as the semester progressed, students voluntarily moved away from their computers and freely moved their chairs around the classroom in order to interact with me and other students, being less retrained by the rigid structure of the physical classroom environment.

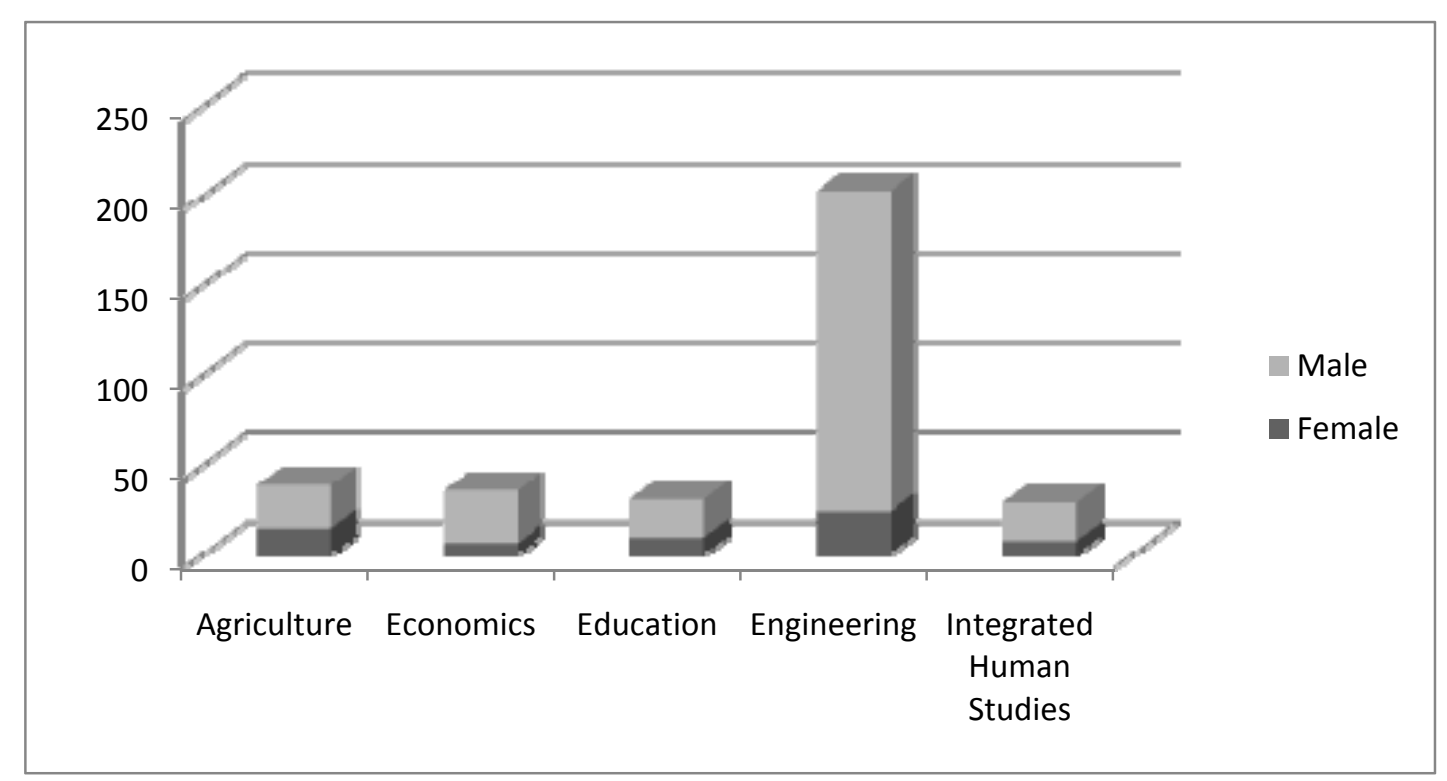

Figure 1. Distribution of students across majors

\subsection{Data Collection, Material, and Instruments}

Students in all 10 classes were assigned an in-class activity were asked to write short responses to Obokata's plagiarism of her PhD thesis (see Appendix for details on the incident) in a Microsoft Word document, while practicing writing and topic sentences for paragraphs. Students were also asked to fill out a consent form. To ensure that students were familiar with the incident, a news video was shown in Japanese with English subtitles of Obokata apologizing at a press conference on April 9, 2014. Students were also given two news articles in English on the incident to read. The expositions were collected through the CaLabo computer system. The following class, the students were then given another opportunity to fine-tune and elaborate on their responses based on feedback provided to the whole class and through small-group discussion with peers.

\subsection{Data Analysis}

\subsubsection{Narrative Analysis as a Tool for Exploring Human Perception}

This study will utilize thematic narrative analysis of essay responses to an open-ended question to determine student perceptions of plagiarism. Thematic narrative analysis was developed in the 1960s to add personal stories to traditional social sciences interpretations of phenomena (Riessman, 2008) and has been found to be a useful tool in helping researchers gain a deeper understanding of such phenomena (Temple, 2008). Although the most common forms of data collection for thematic analysis come in the form of in-depth interviews, focus groups, or field observation, as utilized in this study, open-ended essay responses are also viewed by thematic researchers as a valid source of corpus data (Guest, MacQueen, \& Namey, 2012). Thematic narrative analysis is content-driven and inductive with an exploratory and descriptive nature, and is the preferred method in research on behavior over hypothesis-based, confirmatory-structured analyses (Guest, MacQueen, \& Namey, 2012). 


\subsubsection{Use of Narrative Analysis in This Study}

The author used narrative analysis as a tool to discover how students perceive the social and cultural relations of their world, particularly in this study, perceive plagiarism. When coding and analyzing the corpus of texts text analysis of socio-logical tradition (see Tesch, 1990) was employed. In this tradition, text is "analyzed as a proxy for experience in which we are interested in individuals' perceptions, feelings, knowledge, and behavior as represented in the text" (Guest, MacQueen, \& Namey, 2012, p. 9). By searching for meaning within the participant's writing, and themes in the entire collected corpus, the researcher sought to gain insights in both individual students' perceptions of plagiarism, and trends of thought as a whole.

In qualitative analysis, when data is coded the interpretation of the researcher guides the designation of categories based on words and themes in the participant's writing (Li \& Munby, 1996). While carefully reading each summary of the students, the researcher developed categories for coding. While coding data, the researcher bore in mind that the way a narrative is told changes depending on the situation (Riessman \& Quinney, 2005). Furthermore, this analysis took into consideration that when conducting research with participants using languages second to their native languages, the narrative is influenced by words and phrases that the respondent does not know in the language being spoken (Temple, 2008). One risk in coding based on word usage is that the context of the usage of the word is not taken into consideration. Therefore, after searching for words that matched certain categories, the researcher confirmed the categorization by reading the entire text. This coded and categorized data was confirmed by two other university-level EFL researchers/academics in Japan to ensure transferability.

\section{Results}

Due to student absences, 276 students completed the writing activity. For 50 files, it was impossible to ascertain student opinions they answered the question in a way that did not express their opinions. Nonetheless, these files also provided some insight into students' perceptions of plagiarism.

The corpus data was coded once by day, classroom, and computer used, and then subsequently coded again with a separate number to ensure confidentiality. The responses were then coded and aggregated into three categories (refer to Table 1) that were inducted from the data (see Boyatzis, 1998 on inductive coding):

1) Critical: Obokata's act of plagiarism should be treated as a serious offense

2) Sympathetic: Obokata's act of plagiarism should not be treated as a serious offense

3) Unable to determine student opinion

Table 1. Responses by students who believe Obokata committed a serious offense

\begin{tabular}{lll}
$\begin{array}{l}\text { Type of } \\
\text { Response }\end{array}$ & $\begin{array}{l}\text { Number of } \\
\text { responses }\end{array}$ & Sample responses \\
\hline Critical & $144(53 \%)$ & $\begin{array}{l}\text { "I could not think she is a professional researcher in the true sense of the word. And I } \\
\text { am angry a little bit about her because I am a woman who is interested in science } \\
\text { like her. Because I think she did not have enough responsibility for her paper, and } \\
\text { not have enough awareness as one professional researcher...I think she should } \\
\text { respond to this problem more sincerely. So when I write a paper, I try to be careful } \\
\text { about plagiarism." (Student 151) } \\
\text { "I think what she did is one of the worst thing, which scientists do. Scientists are } \\
\text { people who seek truth of science. They must not twist it." (Student 204) } \\
\text { "I think the mistakes of Dr. Obokata cannot be forgiven by anyone. Some people say } \\
\text { that she only did not know how to write a paper correctly, but ignorance is a kind of } \\
\text { crime. She distorted the truth and published the wrong paper. A lot of people around } \\
\text { the world may think that Japanese scientists always alter the result of the } \\
\text { experimentation." } \\
\text { "I want her to stop research about not only STAP cell and but also all of science." } \\
\text { (Student 146) } \\
\text { "She just did not know how important preciseness in paper is. If she will become } \\
\text { polite and proceed her research, we will profit greatly. Therefore, I think that we }\end{array}$ \\
$\begin{array}{l}\text { Sympath } \\
\text { etic }\end{array}$ &
\end{tabular}


should not attack her so hard and encourage her to return her study." (Student 100)

"What Obokata did was definitely wrong but since she apologized and acknowledged her mistake in front of whole world it seems legit to forgive her." (Student 64)

"I think Obokata's plagiarism is bad, but I feel sorry for her. She was not taught that copying without permission. Everyone can make mistakes when he or she do not know what is bad." (Student 10)

"These days in Japan, many people need results instantly, and it is applied to scientists. The Japanese tendency made Obokata to copy." (Student 251)

The vast majority of students indicated that they believed that Obokata should have known better and her plagiarism was wrong, with a varying degree of responses ranging from critical to sympathetic. Acknowledging that the intertwining of a variety of elements that characterize the student responses makes it impossible to separate them into perfect categories, in order to gain a general understanding of student perception on Obokata's plagiarism incident, these responses were further organized into two broad categories for analysis purposes. Critical refers to responses that indicate that Obokata committed a serious offense. This category also includes statements that judge the character of Obokata in a negative light. Sympathetic responses are responses that express that while Obokata was wrong, she deserves a second chance.

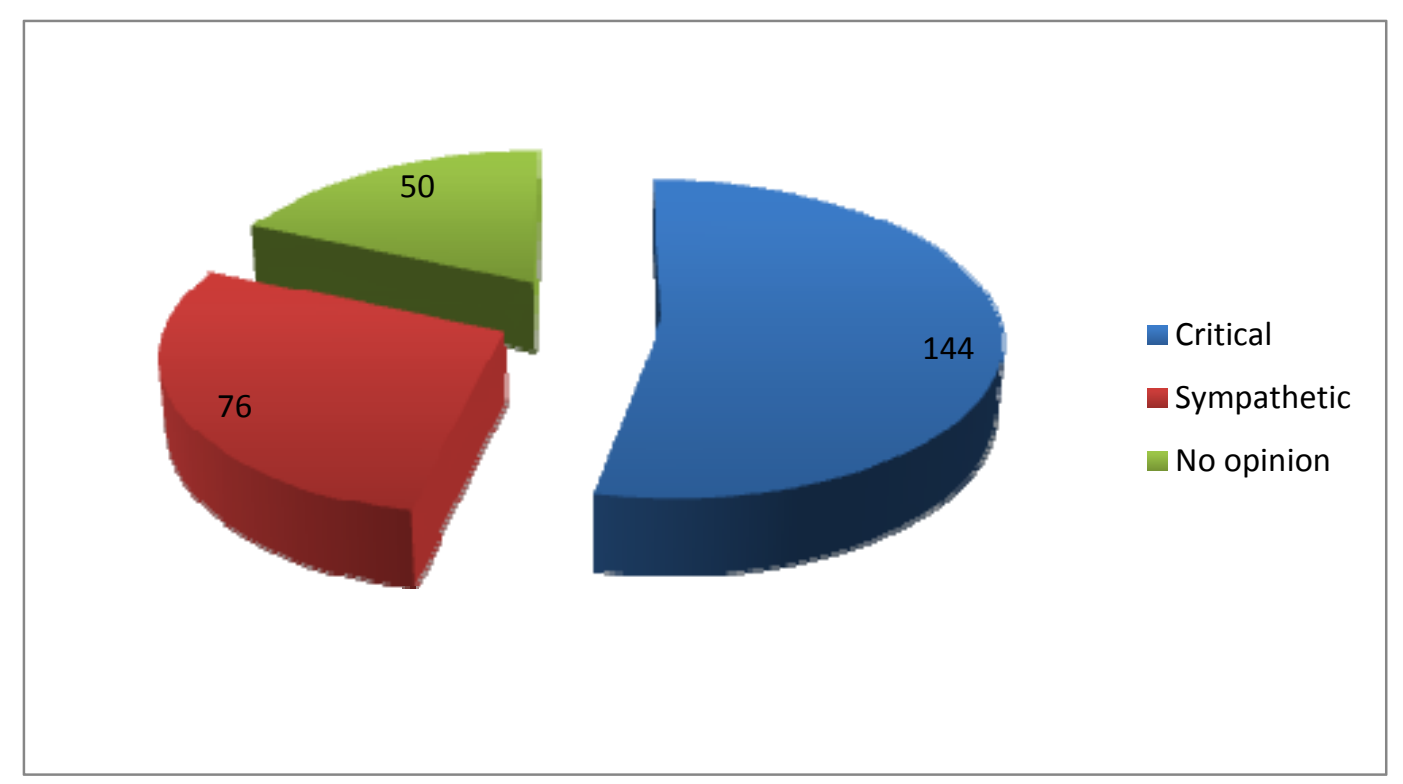

Figure 2. Thematic coded responses of corpus data

Several themes in the student responses marked as critical emerged, touching on perceived character traits of Obokata and how her plagiarizing made students feel. Several students articulated that they felt "betrayed" by Obokata. Common words and phrases in the responses included: "stealing," "lies," "too young," "disappointed," "vanity," "desire to be famous," "immature," "lost credibility," "bad scientist," and "fraud." Numerous students explained that this incident has caused them not to have trust in her research any more. A student that once saw Obokata as a role model expressed anger at her carelessness, also reflecting on how to ensure she does not make the same mistakes as Obokata (see Table 1, Student 144).

Focusing on Obokata's apology at the press conference, 14 students expressed that she had not reflected deeply enough on her behavior:

"But she doesn't think her mistakes are heavy. So she wants to insist STAP cells are exist rather than to apologize her mistakes. I believe that she have to think her mistakes more seriously" (Student 146).

In addition, comments that described students' expectations of scientists were common: 
- "If she is a real researcher, she should not copy other people's paper" (Student 170).

- "In the academic world, it is important to think that who first discovers a new fact or scientific fact" (Student 174).

- "I think everyone should write their own report by themselves [even] if they are busy, and are in trouble of writing report" (Student 182).

- "Dr. Obokata is an evil scientist, because she stole other's ideas and used it in her research. The scientist who originally did the research would have made a lot of efforts to complete his research and write the paper" (Student 189).

Students also reflected on how this incident will inform their own future behavior:

- "I think that she plagiarized because she thought she could make her report more understandable by doing that. But the idea was very wrong. We should pursue the reliability in our report. We must never repeat her failure again. Especially because I am a university student” (Student 201).

- “...when I write a paper, I try to be careful about plagiarism" (Student 151).

- "We should consider more deeply a copyright and how to decide to trust some information and then we should learn to be careful of dealing with information" (Student 7).

Amongst the sympathetic responses, students frequently pointed to societal or educational issues that might have led her to plagiarize. Some common beliefs held by students about education in Japan included:

- Media literacy education is lacking

- Teachers/universities are letting students get away with copying

- Writing practice is insufficient

Societal beliefs included:

- Pressure to publish is too high

- Emphasis on attaining quick results

- Media sensationalism makes it difficult to know the truth

- Plagiarism is rampant

Another type of response focused on the tendency of society to point fingers at one person instead of recognizing that other people are also involved.

Among the remarks that discussed the media coverage of the Obokata incident, many students expressed that they could not form a proper opinion about the plagiarism issue because the tendency for the media to sensationalize made it impossible to know the "truth":

- "What is the biggest problem lies under ourselves. I mean, it is not sensible that people who don't know anything criticize her terribly. It is true about the mass media" (Student 66).

- "I don't know Obokata is really bad. It is true that she made a serious mistake, but there is no exact information about her. Moreover, the way Japanese mass media reports are not right. First, they reported "Rikejo", "Kappogi" and so on, then I wondered why they chose these topics, and thought that these were not very important. They compared "STAP cell" with "IPS cell" in the wrong way. So I cannot trust Japanese mass media, and I don't have a clear opinion about Obokata" (Student 65).

The least frequent response expressed that Obokata's plagiarism bears no influence on the integrity of her work or on her future career- Obokata's discovery of STAP cells is more important than how she presented her data (21 responses). However, while most students whose responses fit in this category prioritize confirming the existence of STAP cells, the majority also indicated that they believed plagiarism was, in essence, unfit for a scientist:

- "What is important is not her mistakes about her report, but why she believes STAP cells exist, and how she proves it to be" (Student 260)

- "Many professors may criticize her. I just want to know whether STAP is true or not" (Student 254)

- "Plagiarism is bad. However, knowing if STAP is true or not is more important" (Student 266)

- “...but she plagiarized. I think she did a bad thing. However she may really discover the way to create STAP-cell. If that, she contributes medical development greatly.” (Student 270) 
A similar, yet slightly difference response by 3 students expressed that the issue of plagiarism and determining whether STAP cells exist should be treated separately, such as student 274 who stated, "Her discovery can change common knowledge in biology and mustn't be neglected on account of mistaking the way of presentation."

Another notable theme was the belief that if Obokata were permitted to pursue her research, albeit in an honest manner, it could only be of benefit to society at large:

I think that she feels sorry about what she did. It is proved she sobbed in her apology. It is true that she was careless in writing her report, but many people shouldn't kid her. I believe STAP phenomenon exists, and want Ms. Obokata to continue her research. If she continues her research, she will get Novel Award as well Mr. Yamanaka in Kyoto University. I believe she can encourage women all over the world! (Student 96)

\section{Discussion and Wider Implications}

While the author's cultural and theoretical background may have slightly influenced interpretation of the results, strong evidence was found to support the need to challenge assertions found in the studies outlined above, that Japanese students believe plagiarism is acceptable. While a large proportion of the students exhibited sympathetic and understanding tendencies about the societal influences that might lead a person to plagiarize, this does not suggest that students believe plagiarism is forgivable or that there are extenuating circumstances that make plagiarism inevitable. Rather, the students surveyed overwhelmingly believe that plagiarism is matter of serious concern. Several students noted a perceived high rate of plagiarism amongst scientists. Nonetheless, many students also indicated a desire to ensure that they receive proper education and training so that they could become "expert researchers."

Although more research needs to be conducted in order to more fully understand students' perceptions of plagiarism, the results point to a more layered and intricate perception than previous studies have suggested. As explained above, one explanation for why such studies to date have demonstrated an apparent acceptance of plagiarism in Japan may be due to the quantitative nature of past multiple choice surveys, which tends to confine student responses into decontextualized boxes that eliminate diversity of opinion, rather than examining the variety of factors that lead a student to choose/make a statement. In this study, students were given a chance to respond to a contextual situation (Obokata's plagiarized work). Contextualized, or as Freire (1970, p. 77) terms it, "situated" situations are critical for helping students to find meaning in their own experiences, interactions with writing, and their lived experience (Freire, 1970, p. 77). This type of contextualizing facilitates a deeper interaction with concepts, in this case, plagiarism, that helps both students and researchers examine the varied and multi-layered perceptions students have of texts and writing.

Another factor could be that it is extremely difficult to conduct intercultural and cross-cultural comparisons on plagiarism. Terminology is always cultural specific, and it often impossible for words to be perfectly translated across languages. Furthermore, it may be the case that some cross-cultural studies have inconsistent results if they neglect to take into consideration the varying lifestyles, societies, and cultures of the participants when making comparisons. Therefore, it is likely more valuable to conduct surveys of attitudes within one cultural setting.

These findings have important implications for pedagogy. In contrast to other research, students demonstrated reflective awareness of the intertwining factors that play a role in a person's decision to plagiarize. Students implied in their responses that this incident should inspire changes in the education system and pinpointed societal problems that must be addressed so that people are not tempted to plagiarize. Like other students in English-speaking countries, students desire to be taught how to write and research effectively and accurately.

When considering pedagogy, it certainly is important to take cultural differences into consideration. However, given these responses, it would not be appropriate for educators to simply overlook plagiarism as something that cannot be helped due to assumed cultural difference. Drawing upon the work of Kubota (1999), practitioners need to understand how social and economic issues produce a discourse that influences the attitudes of students to their engagement with academic work and empower them to understand this for themselves. If educators seek to understand the complexities surrounding the classroom the pedagogical space and the experiences students have in writing will "better assist international students in their writing without silencing their own voices and discouraging their creativity" (Le Ha, 2006, p. 78). It is important that teachers work to transform the prevailing rhetoric about students from a condescending one, to one that has faith in student capability.

Some of the educational and societal concerns mentioned by students included a lack of time, pressure to produce results immediately, and lack of enforcement of academic penal codes. Teachers can guide students to 
techniques to allocate time for writing papers, researching, and generating ideas for papers. Other time saving techniques that teachers can show students is how to keep a research notebook and how to use referencing and citation software to store research notes and material. Most importantly, teachers can facilitate student reflection on the system as a whole. Students can be encouraged to analyze what creates the pressure to produce quickly in society, and also why there is a lack of enforcement of academic integrity standards. Students can also be guided to engage in critical dialogues on academic integrity standards and how they are situated in the Japanese context. Based on these discussions, students can develop their own unique strategies to find empowerment amidst the system.

In terms of enforcing policies on plagiarism and academic integrity, universities in Japan can help raise student awareness of techniques for writing in their own words and proper citation of sources by incorporating these tasks into entrance exams. While, as previously noted, textbooks in high school provide instruction for students to cite and reference sources, the method of doing so is not explained enough in detail. The research of Lee and Tajino (2008) notes that students find citation not as difficult as other types of skills required for academic writing, while summarizing is seen as relatively difficult. Since high schools dedicate an enormous amount of time preparing students for these exams, if academic writing skills such as citation writing and paraphrasing were to become a part of entrance exams, high schools will be more likely to teach these skills to students at younger ages. Although this does not apply to the center exam for entrance into public (and some private) universities, where there are only multiple-choice answers, as Sadoshima (2014) suggests, essay questions in entrance exams can become more targeted. Instead of simply asking a student to write their opinion on a topic, test questions can require students to use certain provided data to make an argument for or against a certain issue. Furthermore, a space can be left on test paper marked "References" so that students know that they must at least write references. Explicit instructions in these exams to use citations can also be utilized.

Japanese universities can also work on making academic integrity policies and procedures clearer and more accessible to students. This can be accomplished through: mandatory seminars for teachers and students on academic integrity, including citation information online, and the standardization of academic integrity policies university- or department-wide. Furthermore, an academic integrity board where both students and teachers consult/report incidents of plagiarism through an intermediary to eliminate power dynamic issues can be created. Opportunities for teachers and students to use free software, such as Turnitin and Endnote, to check for plagiarism and organize references can be made available. Most importantly, students and teachers should be involved in developing and critiquing policies on academic integrity.

Finally, this study is certainly bound by limitations. Since students were required to write during class in a language second to their own, many students did not have time to fully express their opinions (see Agostinho, 2005 for a study on expression of opinions in a second language). Furthermore, the classroom is just one type of reality, a socialized and unnatural reality that shapes student performance, whether positively or negatively. It cannot be assumed that students always perform their best in this environment. In addition, the teacher's attitudes and presentation also could have influenced student responses as well as other factors that come into play in an educational institution environment.

\section{Conclusions}

In contrast to the contentions of several previous researchers, students in this study demonstrated a multi-faceted awareness of the nature of plagiarism as well as an understanding of the educational and societal influences that lead people to resort to plagiarism. This more complicated picture of student perceptions was revealed by allowing student to interact with a contextualized situation- the revelation of plagiarized work in the $\mathrm{PhD}$ thesis and article submission to Nature on STAP cells by Japanese stem-cell biologist Haruko Obokata. Their responses to the Obokata incident lends evidence to the fact that students are not ambivalent towards plagiarism, but rather demand better training from their educational institutions, similar to students in native English speaking countries.

The overwhelming majority of students in the authors' classes did not approve of Obokata's behavior. Whether their essays were extremely critical or sympathetic, the reflective nature of the student responses point to a need for education that equips them with the ability to develop critical techniques for functioning in the academic world. Students are also aware of the gaps in educations and the societal restraints that could cause a person to be tempted to plagiarize. Amongst these students are those who have indicated that they are hopeful that Obokata will become a better scientist so that her work can effectively contribute to knowledge in the scientific community. Students, regardless of their culture, deserve a chance to develop to their full potential, not be constrained by labels based on improper interpretations of their culture and behavior. 
In order to facilitate the development of effective educational techniques, further research needs to be conducted on students' understandings of what plagiarism entails as well as appropriate and effective methods to teach how to write without plagiarizing. Although this research shows that students are overwhelmingly aware that plagiarism is not acceptable in academic communities, more research needs to be conducted on how much students turn to plagiarism, whether intentional or unintentional, in their writing in both Japanese and foreign language writing. While this study provides a snapshot of students' ideas about plagiarism at one university and mostly science majors, other qualitative studies could be conducted to reveal how the influence of other factors on students perceptions of plagiarism. Finally, the influence of institutional definitions and guidelines on academic dishonesty on student and teacher attitudes can also be explored.

Should educators acknowledge the multiple experiences, ideas, and concerns with academic writing, in this particular case plagiarism, effective teaching strategies can emerge. The Obokata incident has shed light on a need for universities and high schools to dedicate more attention to ensuring students' are equipped with academic writing skills, and whether it be through textbook reform or incorporating academic writing tasks into entrance examinations, educational solutions that engage students in critical interactions with the dominant academic sphere, can potentially make an impact.

\section{References}

Agostinho, S. (2005). Naturalistic inquiry in e-learning research. International Journal of Qualitative Methods, 4(1), 1-13. Retrieved from http://www.ualberta.ca/ iiqm/backissues/4_1/html/agostinho.htm

Aotani, M. (2013). Eigo gakushū. TOEFL setsumei kai (English studies and TOEFL Orientation). Aotani no Homepage. Retrieved from http://aoitani.net/TOEFL_12.html

Apple, M. W. (1993). The politics of official knowledge: Does a national curriculum make sense. Teachers College Record, 95(2), 222-241. Retrieved from http://web.stanford.edu/class/educ232b/Apple.pdf

Bailey, A. A. (2002). Moving beyond "groupism" and other cultural myths in Japanese university English Classes. Ritsumeikan Keizaigaku, 40(6), 171-185.

Boyatzis, R. E. (1998). Transforming Qualitative Information: Thematic analysis and Code Development. Thousand Oaks, London, \& New Delhi: SAGE Publications.

Bretag, T., Mahmud, S., Wallace, M., Walker, R., McGowan, U., East, J., ... James, C. (2013). 'Teach us how to do it properly!' An Australian academic integrity student survey. Studies in Higher Education, 39(7), 1150-1169. http://dx.doi.org/10.1080/03075079.2013.777406

Connolly, P. (2009). Ethics in action: A case-based approach. Malden, MA: Wiley-Blackwell.

Cyranoski, D. (2014, April 1). Stem-cell scientist found guilty of misconduct. Retrieved from http://www.nature.com/news/stem-cell-scientist-found-guilty-of-misconduct-1.14974

Cyranoski, D. (2014, March 18). Stem-cell method faces fresh questions (p. 283). Nature.

Day, M. (2009). A meshing of minds: the future of online research for print and electronic publication. New Words: Exploring Pathways for Writing about and in Electronic Environments (pp. 251-277). Retrieved from www.engl.niu.edu/mday/meshing.htm

Dordoy, A. (2002). Cheating and plagiarism: Student and staff perceptions at Northumbria. Paper presented at the Proceedings of the Northumbria Conference-educating for the future, Newcastle upon Tyne.

Franklyn-Stokes, A., \& Newstead, S. E. (1995). Undergraduate cheating: Who does what and why? Studies in Higher Education, 20(2), 159-172. http://dx.doi.org/10.1080/03075079512331381673

Freire, P. (1970). Pedagogy of the oppressed. New York: Herder and Herder.

Gouda, R. (2014, April 7). Wasedadai, hakase ronbun 280 hon o chōsa fusei no utagai shiteki uke (Waseda University to investigate 280 doctoral theses).

Guest, G., MacQueen, K. M., \& Namey, E. E. (2012). Applied Thematic Analysis. Thousand Oaks, SAGE Publications.

Hoshino, T. (2008). <Gakunai no me: watshi no jūgyō> kopī \& pēsutogata gakusei ni dō nozomu ka? (How to deal with copy pasters?). Tsukuba Förumu, 79(1), 52-56. Retrieved from http://ci.nii.ac.jp/naid/120000835529/

Hutton, C. (1990). Originality as an academic requirement. Unpublished paper presented at the Conference on the Teaching of English Language/Literature in the Hong Kong Context, Chinese University of Hong Kong. 
Iwasaki, H., Koide, T., Terada, Y., \& Katsufuji, T. (2014). Obokata haruko shi no hakase gakui ronbun nitaisuru chōsa hōkoku sho' ni taisuru Waseda daigaku daigakuin senshin rikō gaku kenkyū ka kyōin yūshi no shoken (Voluntary opinion of a Waseda University Advanced School of Science and Engineering professor on the investigative report of Obokata Haruko's doctoral thesis). Katsufuji Lab, Waseda University. Retrieved from: http://www.f.waseda.jp/katsuf/Takuro/20140725v2.pdf

Kagakugijutsu Gakujitsu shingikai Kenkyū Katsudō no Fusei Kōi ni Kansuru Tokubetsūnkai (Special Committee on Academic Dishonesty in Research of the Commission of Inquiry on Science and Technology). (2006). Kenkyū katsudō no fusei kōi he no taiō no gaidorain ni tsuite (Guidelines for responding to incidences of academic dishonesty in research activities). C. Ministry of Education, Sports, Science, and Technology (MEXT) (Ed.). Retrieved from www.mext.go.jp/b_menu/shingi/gijyutu/ gijyutu12/houkoku/_icsFiles/afieldfile/2013/05/07/1213547_001.pdf

Klein, I. (1990). Teaching in a Liberal Arts College: How Foreign Language Courses Contribute to "Writing Across the Curriculum" Programs. The Modern Language Journal, 74(1), 28-35. http://dx.doi.org/10.2307/327940

Kobayashi, K. (2010). Daigakusei no jikkenrepōto ni miru inyō no gijutsu (Undergraduate students' skills of referencing in their experimental research papers). Fukuoka Daigaku Kyōiku Kenkyū Hōkoku (Kyōsai Kyōiku Gakuron), 41(1), 77-90. Retrieved from http://ir.lib.shizuoka.ac.jp/bitstream/10297/5270/1/ 100909001.pdf

Kokugo. (2013). Tokyo: Mitsumura Tosho.

Kokugo sanshita: Aozora (Blue sky: Japanese 3rd year second semester). (2012). Tokyo: Mitsumura Tosho.

Kubota, R. (1999). Japanese Culture Constructed by Discourses: Implications for Applied Linguistics Research and ELT. TESOL Quarterly, 33(1), 9-35. http://dx.doi.org/10.2307/3588189

Kyōto University. (2012). Shinro sangyōbetsu shūshoku jōkyō (Career distribution of graduates by job category). Retrieved July 15, 2012, from http://www.kyoto-u.ac.jp/contentarea/ja/issue/ku_profile/documents/2012/ gaiyo12_15.pdf

Le Ha, P. (2006). Plagiarism and overseas students: Stereotypes again? ELT Journal, 60(1), 76-78. http://dx.doi.org/10.1093/elt/cci085

Lee, S., \& Tajino, A. (2008). Understanding students' perceptions of difficulty with academic writing for teacher development: A case study of the University of Tokyo writing program. Kyōtodai gaku kōtō kyōiku kenkyū, 14(1), 1-11. Retrieved from http://repository.kulib.kyoto-u.ac.jp/dspace/bitstream/2433/70833/1/01_ Nancy.pdf

Li, S., \& Munby, H. (1996). Metacognitive strategies in second language academic reading: A qualitative investigation. English for Specific Purposes, 15(3), 199-216.

Liu, D. (2005). Plagiarism in ESOL students: Is cultural conditioning truly the major culprit? English Language Teaching Journal, 59(3), 234-241. http://dx.doi.org/10.1093/elt/cci043

Macbeth, K. P. (2006). Diverse, Unforeseen, and Quaint Difficulties: The Sensible Responses of Novices Learning to Follow Instructions in Academic Writing. Research in the Teaching of English, 41(2), 180-207. Retrieved from http://www.jstor.org/stable/40171696

Maddox, J. (1995 August 31). Plagiarism is worse than mere theft. Nature, 376, 721. http://dx.doi.org/10.1038/376721a

Marsden, H., Carroll, M., \& Neill, J. T. (2005). Who cheats at university? A self-report study of dishonest academic behaviours in a sample of Australian university students. Australian Journal of Psychology, 57(1), 1-10. http://dx.doi.org/10.1080/00049530412331283426

Newton, F. J., Wright, J. D., \& Newton, J. D. (2014). Skills training to avoid inadvertent plagiarism: Results from a randomised control study. Higher Education Research \& Development. http://dx.doi.org/10.1080/07294360.2014.911257

Nishigaki, J. (2012). Gakushi katei gakusei ni taisuru senkō kenkyū no inyō ni kansuru repōto shidō jugyō no kaihatsu to sonokekka ni kan suru kentō (Development and evaluation of an undergraduate instructional session on appropriate citations in academic essays). Osaka Shiritsu Daigaku Daigaku Kyōiku (Osaka City University Journal of Educational Studies), 10(1), 1-12. Retrieved from http://dlisv03.media.osaka-cu.ac.jp/infolib/user_contents/kiyo/DBn0100101.pdf 
Obokata, H., Wakayama, T., Sasai, Y., Kojima, K., Vacanti, M. P., Niwa, H., ... Vacanti, C. A. (2014). Stimulus-triggered fate conversion of somatic cells into pluripotency. Nature, 505(7485), 641-647. http://dx.doi.org/10.1038/nature12968

Obokata shi no hakase ronbun meguru sōdai hōkoku sho, yūshi no kyōju ra mondai shi (Professors speak out against Waseda report on Obokata's PhD thesis). (2014). Asahi Shinbun. Retrieved from: http://www.asahi.com/articles/ASG7S6WQZG7SULBJ015.html

Oshima, Y. (2010). Daigaku shonenji no repōto ni okeru ronshō no danwa bunseki (Sasaki Yoshinori sensei suitō kinnen gō) (Discourse Analysis of the Discussions of Essays Written by First Year University Students (Dedicated to the Memory of Dr. SASAKI Yoshinori)). Gengō Bunka to Nihongo Kyōiku, 39, 84-93. Retrieved from http://teapot.lib.ocha.ac.jp/ocha/bitstream/10083/52015/1/14_84-93.pdf

Pecorari, D. (2003). Good and original: Plagiarism and patchwriting in academic second-language writing. Journal of Second Language Writing, 12(4), 317-345. Retrieved from http://dx.doi.org/10.1016/j.jslw.2003.08.004

Pennycook, A. (1996). Borrowing others' words: Text, ownership, memory, and plagiarism. TESOL Quarterly, 30(2), 201-230. http://dx.doi.org/10.2307/3588141

Riessman, C. K., \& Quinney, L. (2005). Narrative in social work: A critical review. Qualitative Social Work, 4(4), 391-412. http://dx.doi.org/10.1177/1473325005058643

Riessman, C. K. (2008). Narrative methods for the human sciences. London \& Thousand Oaks: Sage Publications.

Rinnert, C., \& Kobayashi, H. (2005). Borrowing words and ideas: Insights from Japanese L1 writers. Journal of Asian Pacific Communication (John Benjamins Publishing Co.), 15(1), 31-56. http://dx.doi.org/10.1177/1473325005058643

Sadoshima, S. (2008, June 9). Nihon no daigaku ni okeru akademikku raithing shidō (Academic writing tutoring in Japanese University). Yomiuri Shinbun Online. Retrieved from: www.yomiuri.co.jp/adv/wol/opinion/international_080609.html

Sadoshima, S. (2014). Academikku raitingu kyōiku to jōhō riterashī: (Jōhō wo saiteigi) shi iken wo kōsakudekiru gakusei wo sodateru (Tokushū jōhō riterashī)) Information literacy and academic writing education: Helping students to process information $(<$ Special feature $>$ Information literacy)) (Information literacy and academic writing education: Helping students to process information ( $<$ Special feature>Information literacy). Jōhō no Kagaku to Gijutsu (Information Science and Technology), 64(1), 22-28. Retrieved from http://ci.nii.ac.jp/naid/110009686623/

Schlanger, Z. (2014, April 1). Haruko Obokata, Who Claimed Stem Cell Breakthrough, Found Guilty of Scientific Misconduct. Newsweek. Retrieved from http://www.newsweek.com/haruko-obokata-whoclaimed-stem-cell-breakthrough-found-guilty-scientific-239000

Schules, D. (2014, May 27). Taking aim at Japan's gender problem. The Japan Times. Retrieved from http:/www.japantimes.co.jp/opinion/2014/05/27/commentary/japan-commentary/taking-aim-japans-gender -problem/\#.U-XqWICSwWI

Senshin rikō gaku kenkyū ka ni okeru hakase gakui ronbun ni kansuru chōsa iin kai (Waseda University School of Advanced Science and Engineering Doctoral Thesis Investigation Committee). (2014). Senshin rikō gaku kenkyū ka niokeru hakase gakui ronbun nikansuru chōsa iin kai chōsa hōkoku sho gaiyō (School of Advanced Science and Engineering Doctoral Thesis Investigation Committee Report). Waseda University, 1-5. Retrieved from http://www.waseda.jp/jp/news14/data/140328_committee.pdf

Shibata, K. (2011). Kokusai ka jidai niokeru igaku eigo kyōiku (Medical English education in international age). Kawasaki Ikaishi Ippan Kyō, 37(1), 77-82. $\quad$ Retrieved from http://igakkai.kms-igakkai.com/wp/wp-content/uploads/2011ky/ippannkyouyou37.77-82.2011.pdf

Sowden, C. (2005). Plagiarism and the culture of multilingual students in higher education abroad. ELT Journal, 59(3), 226-233. http://dx.doi.org/10.1093/elt/cci042

STAP retracted. (2014). Nature, 511(1), 5-6. Retrieved from: http://www.nature.com/polopoly_fs/1.15488! /menu /main/topColumns/topLeftColumn/pdf/511005b.pdf

Temple, B. (2008). Narrative analysis of written texts: Reflexivity in cross language research. Qualitative Research, 8(3), 355-365. http://dx.doi.org/10.1177/1468794106093632 
Tesch, R. (1990). Qualitative research: Analysis types and software tools. New York:Falmer Press.

U.S. Department of Health and Human Services (HHS). (2005). 42 CFR Parts 50 and 93 Public Health Service Policies on Risconduct. Rearch Retrieved from http://ori.hhs.gov/sites/default/files/42_cfr_parts_50_and_93_2005.pdf

Waseda: Obokata committed plagiarism but can keep doctorate. (2014, July 18). Asahi Shinbun. Retrieved from http://ajw.asahi.com/article/behind_news/social_affairs/AJ201407180049

Wheeler, G. (2009). Plagiarism in the Japanese universities: Truly a cultural matter? Journal of Second Language Writing, 18(1), 17-29. http://dx.doi.org/10.1016/j.jslw.2008.09.004

Yamaguchi, K. (2014, July 22). Gakumon, kenkyū no rinri to nippon no daigaku. kenkyū kikan no shinyō futatabi Obokata shi mondai ni yosete (Scholarship and research ethics of universities in Japan. The trustworthiness of research institutes- reassessing the Obokata issue). The Research Institute of Economy, Trade and Industry. Retrieved from http://www.rieti.go.jp/jp/columns/a01_0403.html

Yamamoto, J. (2001). Jinbun shakaikei kenkyūsha no seitai to kenkyū jō no rinri (<Tokushū>: Kagaku jōhō no rinri) (Special feature: Scientific misconduct, the lives and academic ethics of social scientists and humanists in Japan). Jōho no Kagaku to Gijutsu (Information Sciences and Technology), 51(12), 624-629. Retrieved from http://ci.nii.ac.jp/naid/110002829651/

\section{Appendix}

\section{Background on the Obokata Incident}

In January 2014, Obokata announced the discovery of a simple method of producing Stimulus-Triggered Acquisition of Pluripotency (STAP) cells, a type of cell that can potentially repair body tissue, in the English-language scientific journal Nature (see Obokata et al., 2014). Her groundbreaking discovery has generated enormous media attention because she supposedly developed a new method for generating these stem cells, with capabilities beyond the pluri-potent stem cells the Nobel Prize winner Shinya Yamanaka discovered previously. Following the publication of the article, doubt was cast on the viability of her research and she was found guilty of "manipulat[ing] data [in the article] with the intent to mislead" (Schlanger, 2014, April 1). Parts of the article were found to be near copies from other sources ("STAP retracted," 2014).

Subsequently, the accountability of her $\mathrm{PhD}$ thesis was called into question prompting an examination by her alma mater, Waseda University. The School of Advanced Science and Engineering Doctoral Thesis Investigation Committee (2014, p. 2) concluded that 11 parts of her dissertation (written in English) had been plagiarized, but has decided not to revoke her doctoral degree. Nonetheless, professors from the same department have voiced their opposition to the committee's decision pointing out that nearly 20 pages of her dissertation are a near copy of a document on stem cells published by the U.S. National Institutes of Health (Cyranoski, 2014, March 18; Iwasaki, Koide, Terada, \& Katsufuji, 2014; “Obokata shi," 2014). Meanwhile, Waseda University has announced that it will examine the 280 doctoral theses it has approved since the founding of the department in 2007 (Gouda, 2014, April 7).

Interestingly, much of the media commentary and criticisms of Obokata, even prior to the accusations of academic dishonesty, focuses on her gender and age (Schules, 2014, May 27). In the meantime, Obokata has claimed that she had mistakenly submitted the wrong photo for inclusion in the Nature article, and that she had inadvertently submitted a draft of her PhD thesis, not the final version (Cyranoski, 2014, April 1; "Waseda: Obokata committed plagiarism but can keep doctorate," 2014, July 18). Nonetheless, academics are concerned that the integrity of Japanese academia will suffer if Obokata is not made to face stricter consequences for plagiarizing her thesis (Yamaguchi, 2014, July 22).

\section{Copyrights}

Copyright for this article is retained by the author(s), with first publication rights granted to the journal.

This is an open-access article distributed under the terms and conditions of the Creative Commons Attribution license (http://creativecommons.org/licenses/by/3.0/). 